\title{
Islam and Malay in Borneo
}

Pontianak: IAIN Pontianak Press, 2015

\author{
By Hermansyah
}

Reviewed By

Dian Kartika Sari

Pontianak State Institute of Islamic Studies

Islam and Malay are undeniably inseparable from Borneo Island. This book elaborates the writer's thoughts about Islam and Malay, especially in Borneo Island. Hermansyah himself was triggered by the small number of literatures or research on Borneo Island. Therefore, those reasons encouraged him to write more about Borneo and its living society. Islam and Malay in Borneo consists of eight chapters that present various kinds of Malay and Islam comprehensively. Chapter one is about the identity of Islam and Malay. To begin with, Malay, once, was considerably identical to Islam. If someone embraces Islam, then he or she will be considered a Malay, no matter his/her ethnic background. Nevertheless, in line with the social and political life, the idea has also been shifted.

Besides, the other chapters also discuss more on how the Islamic life and Malay society thrive in Borneo. The assimilation of cultural and religious practices was used so people would absorb both values effortlessly. Thus, Hermansyah puts an article in chapter two about the islamization of the inlanders: the model of cultural da'wah. In this chapter, the writer emphasizes that Islam was not merely a revealed religion because the spreading process at that time concerned on inclusive and diverse model (Azyumardi Azra on p. 21). Moreover, cultural da'wah utilizes the local culture and is not a limitation between 'pure Islam' and 'syncretic Islam'. The process itself is to accelerate the changes through social-economic and education empowerment.

In addition to the cultural da'wah, the intellectual heritage from the ancestors also shows how the inlanders practiced Islam in the past. In chapter three and four, furthermore, the writer portrays how the texts, literatures, and manuscripts had a major role in islamization. Fiqh book written by Bilal Lumbuk or Haji Massabran which is analysed in this book is a primary source describing the unique islamization process in the rural area of West Kalimantan. The manuscript sheds light not only on fiqh matters but also aqidah and tasawwuf which were taught by sufis in the past. Moreover, the 
pattern of Islam at that time was simpler to perform as the religious values spread but not ignoring the local wisdom. Thus, Islamization was acceptable and easy to follow for some communities.

The manuscript contributes the unique information of some communities' life, whether it be history, law, education, spiritualism, and so forth. Besides, some of manuscripts analyzed by Hermansyah and some research reveal that Islam could transform the strict local people into open-minded and tolerant Malay (p. 56). Manuscripts are significant to understand people and their aspects of life in the past. Therefore, Hermansyah thinks preserving the manuscripts is an important matter nowadays that the intellectual heritage of the past could be explored entirely. The preservation, nonetheless, could be a process of collecting or digitalizing the manuscripts.

Hermansyah, through his writing, delivers a strong bond between Malay and Islam, and the Islamization process of native inhabitants being Malay people. The sufis, additionally, had a major role on the islamization process through simpler way that came from the local culture and local wisdom. Moreover, the manuscripts - such as religious or mantra books - also documented many materials regarding Islam and Malay. In other chapters, the writer enhances the relation between Islam and Malay that could be found in Mantra books. Then, the discussion continues on how the statement from Mantra books have a strong power to move local people believe in the mantras.

The writer stresses on how the local culture or wisdom affect the way native people act and think. Local wisdom, as well, had opened easier way for ulama, dai, or sufi who brought Islamic values to the local people through assimilation process in the past. The islamization process, furthermore, was easily accepted because the concept and the main values of Islamic doctrine were adapted from local wisdom. Meanwhile, local wisdom could also prevent an enormous conflict from taking place since local people have the same point of view. To wrap up, this book is highly recommended for those who wish to learn more about Islamization, ethnicity, and social life. Eventhough the book is actually the unpublished articles collected by the writer, "Islam and Malay in Borneo" is worth reading. 